\title{
STRATEGI PENINGKATAN MUTU PART BENING MENGGUNAKAN PENDEKATAN METODE SIX SIGMA (STUDI KASUS: DEPARTMENT INJECTION DI PT. KG)
}

\author{
Lithrone Laricha Salomon, Ahmad dan Nickholaus Denata Limanjaya \\ Program Studi Teknik Industri Universitas Tarumanagara \\ Jurusan Teknik Mesin Fakultas Teknik Universitas Tarumanagara \\ e-mail: laricha_salomon@yahoo.com
}

\begin{abstract}
ABSTRAK
Produk part bening yang diproduksi oleh PT KG adalah barang yang rentan dengan reject (cacat) yang tidak dapat diperbaiki sehingga produk cacat tersebut akan dihancurkan dan dijadikan bahan baku ulang. Metode pendekatan Six Sigma digunakan untuk mengidentifikasikan dan mengurangi produk cacat. Penelitian ini fokus pada produksi part bening Big Container 211 PLY dan Big Container 1L AS. Berdasarkan hasil pengolahan data didapat DPMO untuk part bening Big Container 211 PLY sebesar 0,0357 dan tingkat Sigma sebesar 4,015 sigma dan 3,57\% cacat, dilanjutkan untuk part Big Container 1L AS diperoleh DPMO sebesar 0,02088 dengan tingkat sigma sebesar 4,199 sigma dan 2,08\% cacat. Berdasarkan hasil Failure Mode and Effect Analysis (FMEA) rangking tertinggi adakah cacat silver dan retak. Berdasarkan analisis penyebab cacat yang terjadi kemudian dilakukan langkah perbaikan dan implementasi pada proses produksi injeksi part bening didapat nilai sigma sebesar 4,28 sigma dan 1,61\% cacat pada Big Containter 211 PLY, lalu nilai sigma sebesar 4,40 sigma dan 1,09\% cacat pada Big Container $1 L$ AS.
\end{abstract}

Kata Kunci: Six Sigma, Reject, DPMO, FMEA.

\begin{abstract}
The products manufactured by the translucent part PT KG is susceptible to reject the goods (defects) that can not be repaired so that the defective product will be destroyed and re-used as raw materials. Six Sigma method approach is used to identify and reduce product defects. This study focuses on the production of spare nodes 211 Big Container Container 1L Big PLY and the US. Based on the results obtained DPMO data processing for clear part PLY Big Container 211 by 0.0357 and Sigma level of 4.015 and 3.57\% sigma defects, proceed to spare US Big Container 1L obtained DPMO sigma level of 0.02088 with 4,199 of sigma and 2.08\% disability. Based on the results of Failure Mode and Effect Analysis (FMEA) The highest rank is there a silver defects and cracks. Based on the analysis of the causes of defects that occur later performed corrective measures and implementation of the production process transparent part injection obtained sigma value of 4.28 and $1.61 \%$ sigma defects in Big Containter 211 PLY, then sigma sigma value of 4.40 and $1.09 \%$ disability in the US Big Container $1 \mathrm{~L}$.
\end{abstract}

Keywords: Six Sigma, Reject, DPMO, FMEA.

\section{PENDAHULUAN}

Perkembangan Industri semakin hari semakin meningkat. Banyak hasil produk yang dihasilkan dalam industri untuk memenuhi kebutuhan yang diinginkan. Tidak hanya satu industri saja yang menawarkan satu jenis produk, semakin berkembangnya dunia industri makan akan semakin banyak industri yang memproduksi jenis produk yang sama. Dengan adanya industri lain maka akan terjadi persaingan untuk menarik pelanggan. Untuk mempertahankan produk mereka agar tidak disaingi oleh industri lain maka diperlukan standar kualitas. Mutu kualitas menarik perhatian konsumen untuk membeli suatu produk. Dengan begitu untuk menarik konsumen. produk tersebut harus memiliki standar kualitas yang sesuai dengan keinginan konsumen. Tetapi diperlukan juga kebijakan perusahaan untuk mempertimbangkan apa yang diminta oleh konsumen dengan begitu dapat terjadi kesepakatan untuk kepuasaan bersama.

PT. KG adalah salah satu industri alat rumah tangga terbesar di Indonesia. Berbagai produk alat rumah tangga yang dihasilkan seperti rice cooker, blender, kipas angin, setrika, dll yang memiliki brand MIYAKO telah menjadi pilihan utama disetiap rumah tangga. PT. KG selalu memberikan produk yang terbaik dengan kualitas yang terjamin. Pada produk blender menggunakan part bening dimana part bening tersebut rentan akan cacat. 
Produksi ini sering menghasilkan part reject. Part reject yang dihasilkan tidak dapat diperbaiki, sehingga part reject yang dihasilkan akan di-crusher untuk dijadikan ke material semula. Maka diharapkan adanya perbaikan untuk mengurangi produksi part bening yang reject. Penelitian ini akan menggunakan metode pendekatan Six Sigma untuk mengurangi reject pada proses pembuatan part bening Big Container 211 PLY dan Big Container 1L AS.

Dengan metode Six Sigma dapat diketahui apa penyebab dan faktor-faktor yang mempengaruhi terjadinya produk reject dengan tujuan untuk mengurangi produksi yang cacat menggunakan fish bone, FTA, FMEA akan memberikan informasi berupa jenis cacat terbesar yang dihasilkan pada proses injeksi part bening dan memberikan usulan perbaikan dengan metode Six Sigma.

\section{Six Sigma}

\section{TINJAUAN PUSTAKA}

Tujuan dari program peningkatan kualitas Six Sigma ialah untuk memperbaiki sistem manajemen suatu perusahaan atau instansi lain yang terkait dengan pelanggan. Lalu digunakan untuk memperbaiki proses produksi yang difokuskan pada usaha untuk mengurangi varian proses sekaligus mengurangi cacat, sedemikian hingga dapat mencapai 3,4 DPMO. Potensi timbulnya kecacatan memang akan selalu ada, karena tidak ada proses sekalipun sempurna, walaupun proses berlangsung dengan baik dan benar, sesuai dengan yang diharuskan. Pada Six Sigma memiliki tahapan DMAIC [1].

\section{Metode DMAIC}

DMAIC merupakan model yang memiliki 5 fase siklus perbaikan yaitu Define (mendefinisikan), Measure (mengukur), Analyze (menganalisis), Improve (memperbaiki), Control (mengendalikan) sebagai metode untuk memecahkan permasalah produk atau proses [2].

\section{FTA (Fault Tree Analysis)}

FTA merupakan alat penting untuk mengevaluasi keselamatan dan kehandalan dalam desain, pengembangan, dan operasi sistem. FTA menggunakan suatu pendekatan dari atas ke bawah untuk menghasilkan suatu model evaluasi keandalan sistem yang menyajikan baik data kualitatif dan kuantitatif. Tujuan dari FTA adalah untuk mengidentifikasikan terjadinya suatu kegagalan dari berbagai cara, baik dari faktor fisik maupun manusia, yang dapat mengarah pada penyebab terjadinya kegagalan/kesalahan tersebut [3].

\section{Failure Mode and Effect Analysis(FMEA)}

FMEA merupakan salah satu alat six sigma yang sering dipergunakan untuk mengidentifikasi sumber-sumber dan akar penyebab dari suatu masalah kualitas.

\section{PetaKendali}

Peta kendali merupakan suatu diagram yang menunjukan batas-batas dimana suatu hasil pengamatan masih dapat ditolerir dengan risiko tertentu yang menjamin bahwa proses produksi berada dalam keadaan terkendali. Ada 2 macam peta kendali yaitu peta kendali variabel dan peta kendali atribut. Peta kendali dalam penelitian ini akan menggunakan peta kendali P [4].

\section{DPMO}

Perhitungan DPMO dan level sigma bertujuan untuk mengukur kemampuan dan kapabilitas sigma pada saat ini. Adapun nilainilai yang diperlukan untuk menghitung nilai DPMO yang perlu diketahui adalah Unit (U) yang menyatakan jumlah produk yang diperiksa dalam inspeksi, selama waktu pengamatan. Defect (D) yang menyatakan jumlah produk cacat yang terjadi selama waktu pengamatan. Opportunity (OP) menyatakan karakteristik yang berpotensi menyebabkan cacat.

Langkah-langkah yang diperlukan dalam perhitungan DPMOadalah sebagai berikut [4]:

1. Defect per Unit

Perhitungan nilai $D P U$ dapat dilihat di bawah ini yaitu:

$$
D P U=\frac{D}{U}
$$

2. Total Opportunities (TOP)

Perhitungan nilai TOP dapat dilihat di bawah ini yaitu:

$T O P=U \times O P$ 
Perhitungan nilai $D P O$ dapat dilihat di bawah ini yaitu:

$$
D P O=\frac{D}{T O P}
$$

4. Defectper Million Opportunities

Perhitungan nilai DPMO dapat dilihat di bawah ini yaitu:

$$
D P M O=D P O \times 1.000 .000
$$

5. Tingkat Sigma

Perhitungan konversi nilai DPMOmenjadi nilai sigma dilakukan dengan menggunakan microsoft excel dengan rumus perhitungan Konversi Nilai DPMO $=$ NORMSINV $((1.000 .000-\mathrm{DPMO}) / 1.000 .000)+1.5$.

\section{METODOLOGI PENELITIAN}

Metodologi penelitian yang dilakukan diawali dengan penelitian pendahuluan di lapangan, ditemukan masalah pada department injection di PT. KG, yaitu terdapat banyak reject part bening yang berasal dari hasil mold injection part bening. Oleh karena itu, PT. KG merasa perlu adanya perbaikan dalam proses produksi sehingga jumlah reject yang dihasilkan dapat berkurang. Adanya tujuan penelitian yang ingin dicapai, yakni sebagai berikut:

1. Menganalisis faktor-faktor yang berpengaruh terhadap reject di proses injection part bening.

2. Mengetahui jenis-jenis cacat reject yang paling banyak terjadi di proses injection part bening.

3. Memberikan cara untuk meminimumkan reject yang paling banyak terjadi di proses injection part bening dengan metode Six Sigma melihat apakah perbaikan dapat dilakukan.

4. Melakukan implementasi dan menganalisis penerapan solusi dari metode Six Sigma.

Pengumpulan data dilakukan secara langsung dengan pengamatan di lapangan dan melakukan wawancara langsung dengan operator mesin molding injection part bening yang berkaitan langsung di lapangan.

Jika data-data yang diperlukan terkumpul, tahap selanjutnya adalah melakukan pengolahan data untuk menyelesaikan permasalahan yang ada di perusahaan. Langkah-langkah pengolahan data yang dilakukan adalah sebagai berikut:

1. Memberikan informasi data reject yang diamati dan membuat diagram pareto untuk mengklasifisikan cacat dari cacat yang tertinggi sampai yang terendah.

2. Melakukan analisis Define-MeasurementAnalyze-Improve-Control (DMAIC).

3. Pada tahap define, membuat diagram Supplier-Input-Process-Output-Customer (SIPOC).

4. Pada tahap measurement, menghitung nilai sigma dengan perhitungan Defects Per Million Opportunities (DPMO) dan menghitung CL, UCL, dan LCL sesuai dengan rumus peta kendali P-chart.

5. Membuat diagram peta kendali (berisikan perhitungan CL, UCL, dan LCL) lalu menghitung \% reject yang terjadi di lapangan.

6. Pada tahap analyze,membuatFault Tree Analysis (FTA) dan diagram tulang ikan untuk mengetahui penyebab reject part bening.

7. Melakukan Failure Mode and Effect Analysis (FMEA) produksi part bening di bagian department Injection.

8. Pada tahap improve, memberikan usulan cara-cara untuk mengurangi hasil reject .

9. Pada tahap control, melakukan analisis data yaitu perhitungan DPMO dan pembuatan diagram peta kendali P-chart.

Setelah melakukan pengolahan data, maka hasil dari pengolahan data tersebut di analisis. Analisis data berguna untuk mengetahui hasil apa yang didapat dari tahap pengolahan data. Berdasarkan analisis hasil yang telah dilakukan serta melihat kembali tujuan penelitian yang hendak dicapai, maka dapat ditarik kesimpulan dan saran yang mungkin dapat bermanfaat bagi perusahaan dalam upaya pemecahan masalah yang sedang dihadapi.

\section{HASIL DAN PEMBAHASAN}

Permintaan produksi bagian departemen injeksi part bening berasal dari departemen PPIC Data penelitian dapat dilihat pada Tabel 1 dan 2. 
Tabel 1. Data Reject Big Container 211 PLY

\begin{tabular}{lrrr} 
Produksi & Cacat & $\begin{array}{c}\text { Banyak } \\
\text { Produksi }\end{array}$ & $\begin{array}{c}\text { Reject } \\
(\%)\end{array}$ \\
\hline Produksi 1 & 69 & 1783 & 3,87 \\
Produksi 2 & 99 & 2538 & 3,90 \\
Produksi 3 & 102 & 2283 & 4,47 \\
Produksi 4 & 48 & 1088 & 4,41 \\
Produksi 5 & 55 & 1590 & 3,46 \\
Produksi 6 & 183 & 4993 & 3,67 \\
Produksi 7 & 70 & 2318 & 3,02 \\
Produksi 8 & 73 & 1892 & 3,86 \\
Produksi 9 & 159 & 5540 & 2,87 \\
\hline Total & 858 & 24025 & 3,57 \\
\hline
\end{tabular}

Tabel 2. Data Reject Big Container 1L AS

\begin{tabular}{lrrr}
\hline Produksi & \multicolumn{1}{c}{ Cacat } & $\begin{array}{c}\text { Banyak } \\
\text { Produksi }\end{array}$ & $\begin{array}{c}\text { Reject } \\
(\%)\end{array}$ \\
\hline Produksi 1 & 111 & 5508 & 2,02 \\
Produksi 2 & 139 & 7441 & 1,87 \\
Produksi 3 & 412 & 16527 & 2,49 \\
Produksi 4 & 678 & 29423 & 2,30 \\
Produksi 5 & 284 & 14850 & 1,91 \\
Produksi 6 & 420 & 19432 & 2,16 \\
Produksi 7 & 314 & 16015 & 1,96 \\
Produksi 8 & 191 & 9835 & 1,94 \\
Produksi 9 & 366 & 19520 & 1,88 \\
Produksi 10 & 355 & 16608 & 2,14 \\
Produksi 11 & 216 & 11850 & 1,82 \\
Produksi 12 & 240 & 11421 & 2,10 \\
\hline Total & 3726 & 178430 & 2,09 \\
\hline
\end{tabular}

Jenis Reject yang ada diklasifikasikan menjadi 6 bagian yaitu:

1. Silver

Silver merupakan dimana permukaan part bening terdapat tanda atau garis-garis putih yang muncul searah dengan aliran injection. Penyebab terjadinya hal tersebut dikarenakan kelembaban material resin yang masih tinggi, kandungan kelembaban ini berubah menjadi gas yang tercampur dengan material cair di dalam proses injeksi. Hal ini juga dapat disebabkan karena menggunakan material recylce.

2. Retak

Retak pada permukaan part bening. Jenis cacat ini dapat disebabkan karena pada saat pelepasan mold dimana part bening tersebut sudah selesai dibentuk sesuai bentuk mold, pendinginan yang terjadi kurang sempurna sehingga ketika saat part bening tersebut akan dilepas material tersebut lengket dan tertahan pada mold menyebabkan retak, faktor lainnya juga dapat disebabkan oleh material plastik yang mudah pecah dan permukaan mold yang kasar sehingga saat dilakukan pelepasan material tersebut menempel pada mold.

3. Bercak

Bercak merupakan terdapatnya bekas embunan mold yang menempel pada permukaan dimana suhu mold terlalu dingin. Hal ini disebabkan ketika proses pendingan dengan oleh air, temperatur mold terlalu dingin

4. Buram

Buram pada permukaaan disebabkan adanya debu dalam materia. Material yang kurang disaring akan menyebabkan cacat tersebut. Pada cacat ini dapat disebabkan oleh pemberian silicon pada mold yang berlebihan dan menempel pada permukaan mold.

5. Kempot

Kempot kondisi dimana adanya cekungan pada suatu permukaan. Hal ini biasa disebabkan oleh setingan mesin pada saat injeksi yang kurang padat dimana adanya ketidakrataan tekanan dan pendinginan yang tidak sempurna.

6. Short.

Short, kondisi dimana plastik leleh yang akan diinjeksikan kedalam cavity tidak mencapai kapasitas yang ideal atau sesuai setingan mesin. Dikarenakan kecepatan injeksi yang terlalu rendah sehinggga plastik yang diinjeksikan ke dalam cavity dan temperatur mold yang rendah sehingga plastik mengeras terlebih dahulu sebelum memenuhi cavity. Hal ini juga dapat disebabkan karena adanya kotoran pada nozzle sehingga injeksi tidak berjalan dengan lancar

Diagram pareto untuk \% Reject dapat dilihat pada Gambar 2 dan 3.

Langkah selanjutnya adalah melakukan analisis dengan menggunakan metode Six Sigma melalui tahapan Define-Measure-AnalyzeImprove-Control agar dapat mengurangi reject part bening. Setelah dilakukan analisis, akan dibuat langkah-langkah perbaikan untuk mengurangi reject tersebut. 


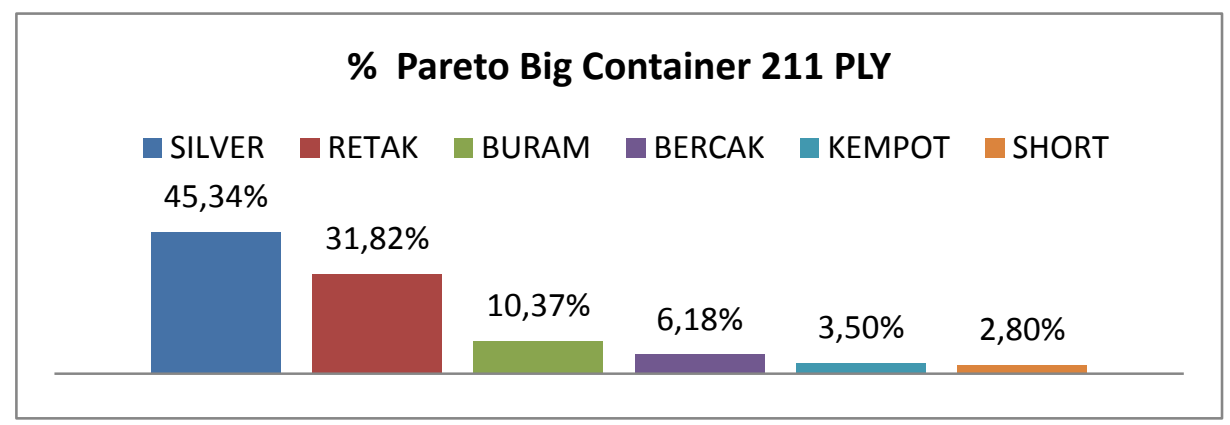

Gambar 2. Diagram Pareto Persentase Big Container 211 PLY

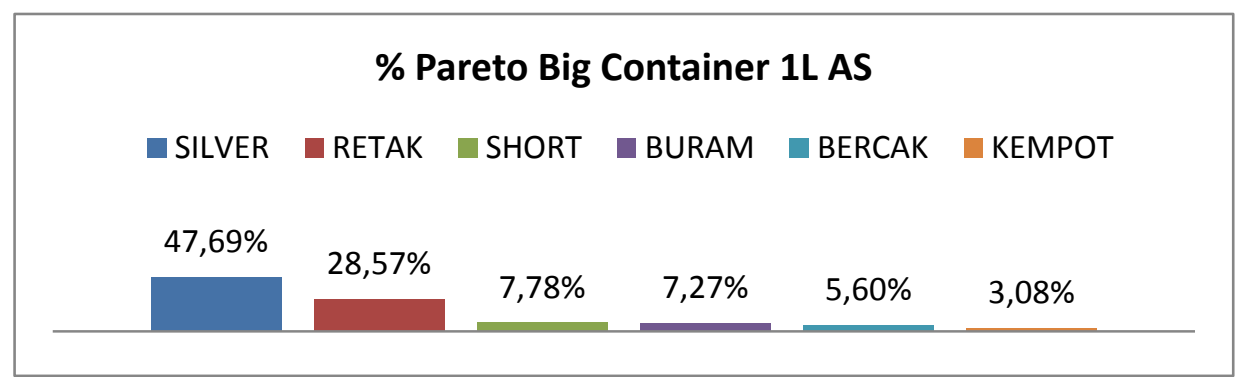

Gambar 3. Diagram Pareto Persentase Big Container 1 L AS

\section{A. Define}

Define atau pengidentifikasian tentang produksi part bening serta menggunakan diagram SIPOC untuk menentukan yang digunakan untuk mengetahui jalannya proses kerja yang ada di perusahaan mulai dari awal hingga akhir dari produk tersebut.

\section{Penentuan Prioritas Penanganan Masalah}

Dalam menentukan produk apa yang akan menjadi prioritas utama dalam penangan masalah, pada bagian departemen injeksi memiliki 2 produksi yaitu part bening dan part PP. Pada produksi part PP sudah memiliki tingkat produksi yang stabil dimana tingkat produksi reject lebih rendah dibandingkan produksi part bening, dikarenakan part bening rentan akan mengalami kecacatan. Pada part bening terjadi banyak hasil part yang cacat. Cacat yang dihasilkan merupakan part yang tidak dapat diperbaiki. Fokus penelitian terdapat pada Big Container 211 PLY dan Big Container $1 \mathrm{~L}$ AS. Diketahui pada departmen injeksi terjadi banyak produksi cacat pada Big Container 211PLY dan Big Container 1L AS yang memiliki kapasitas jumlah produksi tertinggi. Dikarenakan adanya part reject, hasil produksi tidaklah sesuai dengan pencapaian target planning yang sudah diminta. Walaupun hasil cacat dapat di-recycle ulang, penggunaan bahan recycle tidak menjamin bawah cacat tersebut tidak hilang.

\section{Diagram SIPOC}

Diagram SIPOC merupakan alat yang digunakan dalam peningkatan proses, sehingga dapat dilakukan perbaikan terhadap masalah yang ada di dalam proses. Diagram SIPOC menyajikan tampilan singkat dari aliran kerja. Berikut ini merupakan diagram SIPOC proses produksi part bening di PT. KG dapat dilihat pada Gambar 4.

\section{DPMO}

Berikut merupakan perhitungan DPMO untuk menentukan Sigma pada PT. KG dengan penilaian opportunities yang berdasarkan hasil wawancara dengan pihak perusahaan pada Tabel 3 dan Tabel 4 di bawah ini.

\section{B. Measurement}

Tahap pengukuran atau measurement yang dilakukan adalah pengukuran terhadap variabel setiap produksi reject dan jenisnya yang dihasilkan oleh perusahaan PT. Kencana Gemilang pada part bening Big Container 211 PLY dan Big Container 1L AS yang digolongkan cacat sampel variable dan 
pengolahan dengan P-Chart sampel variabel individu. Dapat dilihat pada Gambar 5 dan Gambar 6 dan Tabel 5.

Tabel 3. Perhitungan DPMO Big Container 211

\begin{tabular}{ll}
\multicolumn{1}{c}{ PLY } & \\
\hline Keterangan & Januari-Maret 2015 \\
\hline Unit & 24.025 unit \\
Oportunities & 6 \\
Defect & 858 unit \\
Defect per unit & 0,035712799 \\
Total Opportunities & 144.150 unit \\
Defect Per opportunities & 0,00595213319 \\
DPMO & $5.952,13319$ \\
Tingkat Sigma & 4,015 Sigma \\
\hline
\end{tabular}

Tabel 4. Perhitungan DPMO Big Container $1 \mathrm{~L}$ AS

\begin{tabular}{ll}
\hline Keterangan & Januari-Maret 2015 \\
\hline Unit & 178.430 unit \\
Oportunities & 6 \\
Defect & $3.726 \mathrm{unit}$ \\
Defect per unit & 0,020882139 \\
Total Opportunities & 1.070 .580 unit \\
Defect Per opportunities & 0,0034803564 \\
DPMO & 3480.3564 \\
Tingkat Sigma & 4,199 Sigma \\
\hline
\end{tabular}

Tabel 5. Total Reject

\begin{tabular}{lccc}
\hline \multicolumn{1}{c}{ Jenis Part } & $\begin{array}{c}\text { Total } \\
\text { Produksi }\end{array}$ & $\begin{array}{c}\text { Total } \\
\text { Reject }\end{array}$ & $\begin{array}{c}\text { Reject } \\
(\%)\end{array}$ \\
\hline Big Container 211 PLY & 24.025 & 858 & 3,57 \\
Big Container 1L & 178.430 & 3.726 & 2,09 \\
\hline
\end{tabular}

\begin{tabular}{|c|c|c|c|c|}
\hline Supplier & Input & Process & Output & Customer \\
\hline $\begin{array}{l} \\
\text { PT Chandra Asri } \\
\text { Petrochemical Tbk } \\
\text { PT Halim Samudra } \\
\text { Interutama ABS } \\
\text { Chi Mei Corporation }\end{array}$ & Resin & 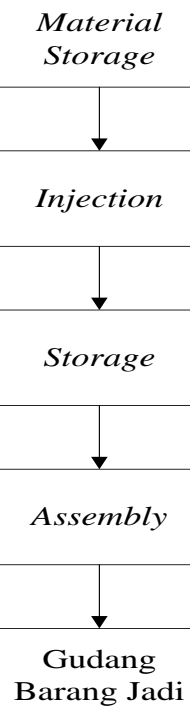 & Blender & $\begin{array}{c}\text { storage } \\
\text { part bening } \\
\text { Assembly } \\
\text { blender }\end{array}$ \\
\hline
\end{tabular}

Gambar 4. Diagram SIPOC

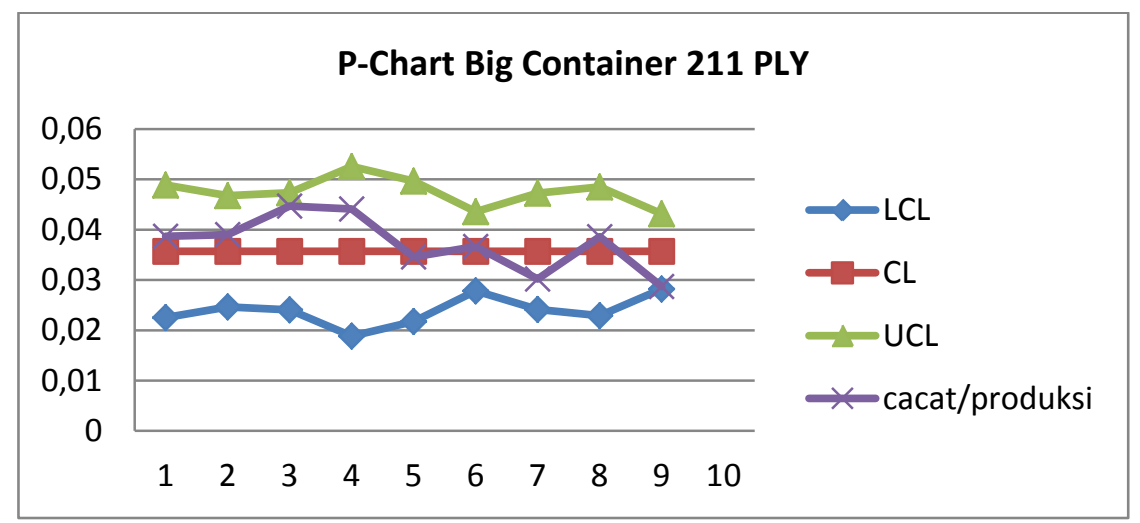

Gambar 5. Grafik Peta Kendali P Big Container 211 PLY 


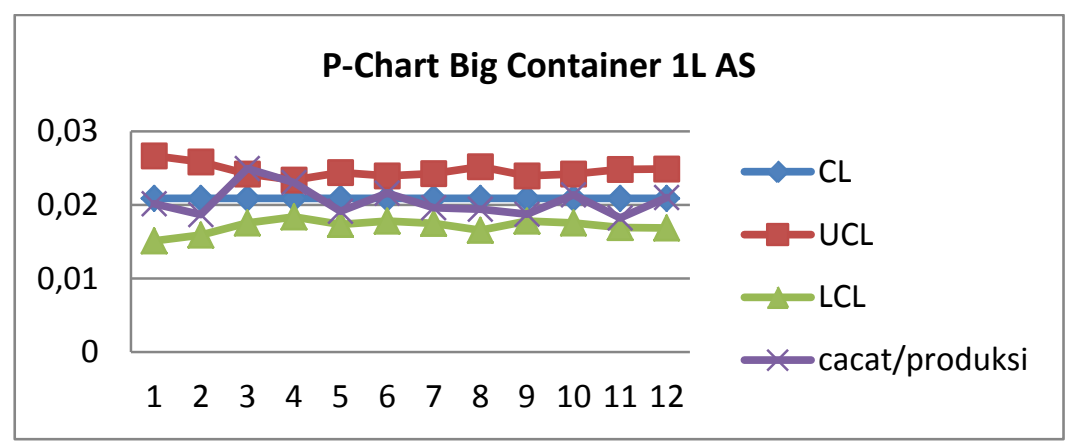

Gambar 6. Grafik Peta Kendali np

\section{Analyze}

\section{Fishbone Diagram}

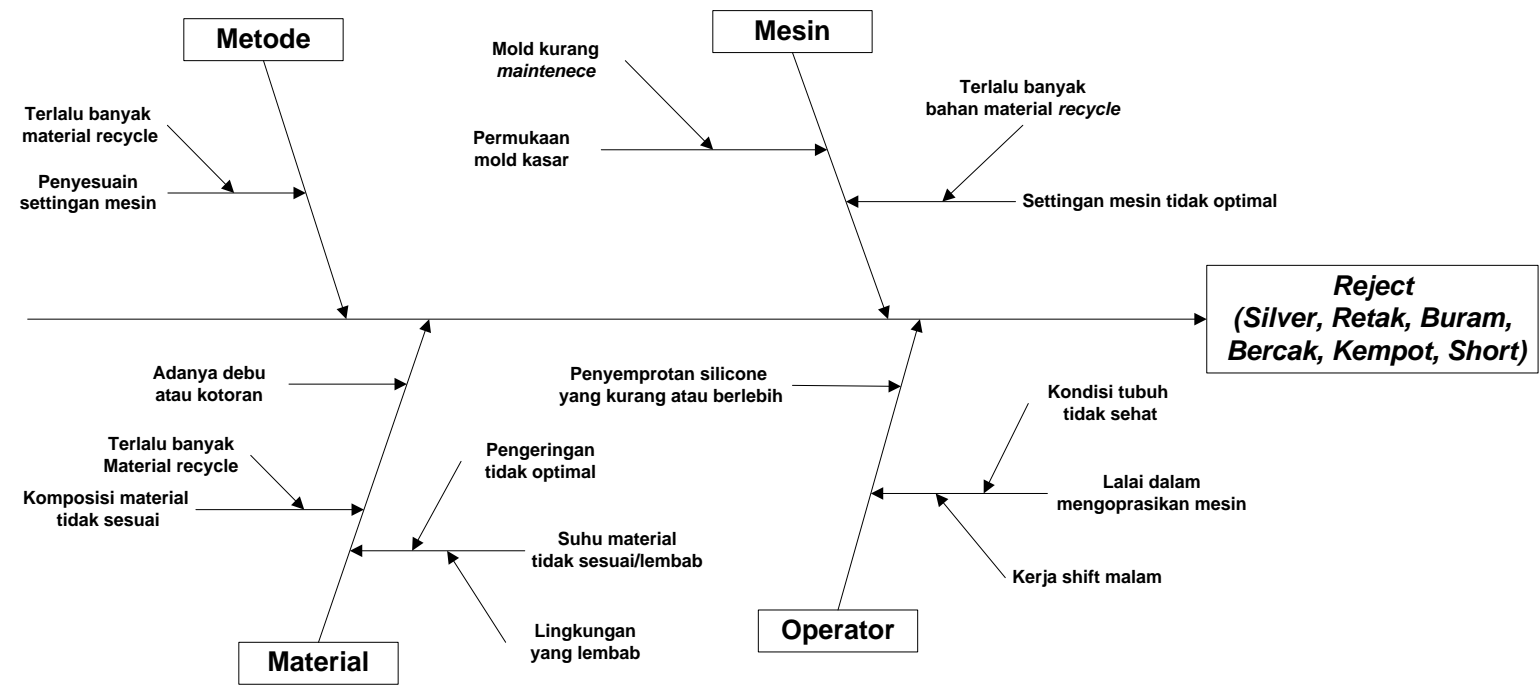

Gambar 7. Fishbone Diagram Big Container 211 PLY dan 1L AS

Diagram yang digunakan untuk mengindentifikasi segala penyebab terjadinya reject pada proses injeksi part bening dari sudut pandang operator, mesin, material, metode. Tujuan dari fishbone untuk mencegah terjadinya kesalahan yang sama di masa mendatang. Dapat dilihat pada Gambar 7.

\section{Fault Tree Analysis}

Dari hasil FTA didapatkan basic event sebagai dapat dilihat pada Tabel 6 .

\section{Failure Mode and Effect Analysis Untuk Proses Injeksi Part Bening}

FMEA berguna untuk menganalisis serta memberi nilai rating bagi kegagalan yang sering terjadi untuk lebih ditangani lebih lanjut guna mengurangi kemungkinan reject yang terjadi. Dapat dilihat pada Tabel 7. Dan karakteristik produk yang diharapkan adalah produk yang bebas dari cacat pada saat proses injeksi.

Tabel 6. Basic Event FTA

\begin{tabular}{|c|c|}
\hline Cacat & Basic Event \\
\hline Retak & $\begin{array}{l}\text { Permukaan mold kasar } \\
\text { Mold menjadi dingin } \\
\text { Tidak presisi }\end{array}$ \\
\hline silver & $\begin{array}{l}\text { Material lembab } \\
\text { Sisa material yang muncul }\end{array}$ \\
\hline Buram & $\begin{array}{l}\text { Silicone menempel pada permukaan part } \\
\text { bening } \\
\text { Adanya debu sisa crusher (ampas) }\end{array}$ \\
\hline Bercak & Air chiller tertinggal pada permukaan mold \\
\hline Kempot & Injeksi kurang padat \\
\hline Short & $\begin{array}{l}\text { Aliran material tersumbat } \\
\text { Pendinginan terlalu cepat }\end{array}$ \\
\hline
\end{tabular}

\section{Improve}

Berdasarkan analisis data di atas maka perlu dilakukan perbaikan pada saat material akan digunakan untuk menghasilkan produksi 
Tabel 7. FMEA Reject Part Bening

\begin{tabular}{|c|c|c|c|c|c|c|c|c|}
\hline $\begin{array}{c}\text { Mode } \\
\text { kegagalan }\end{array}$ & Efek kegagalan & Sev & Penyebab kegagalan & Occ & Kontrol yang dilakukan & Det & RPN & $\begin{array}{l}\text { Rang } \\
\text { king }\end{array}$ \\
\hline \multirow{3}{*}{ Retak } & $\begin{array}{l}\text { Permukaan mold } \\
\text { kasar }\end{array}$ & 8 & $\begin{array}{l}\text { Kurangnya } \\
\text { penyemprotan silicone }\end{array}$ & 7 & $\begin{array}{l}\text { Memberi arahan pada } \\
\text { operator }\end{array}$ & 7 & 392 & 2 \\
\hline & $\begin{array}{l}\text { Mold menjadi } \\
\text { dingin }\end{array}$ & 9 & $\begin{array}{l}\text { Pengambilan produk } \\
\text { yang tidak berkelanjutan }\end{array}$ & 9 & $\begin{array}{l}\text { Melakukan pengambilan } \\
\text { produk dengan } \\
\text { continuous }\end{array}$ & 1 & 81 & 7 \\
\hline & Tidak presisi & 9 & $\begin{array}{l}\text { Setingan injeksi terlalu } \\
\text { padat }\end{array}$ & 7 & $\begin{array}{l}\text { Mengurangi setingan } \\
\text { injeksi }\end{array}$ & 5 & 315 & 4 \\
\hline \multirow{2}{*}{ Silver } & Material lembab & 6 & $\begin{array}{l}\text { Pengeringan material } \\
\text { tidak optimal }\end{array}$ & 8 & $\begin{array}{l}\text { Menunggu material } \\
\text { dikeringkan dalam } \\
\text { hopper }\end{array}$ & 9 & 432 & 1 \\
\hline & $\begin{array}{l}\text { Sisa material } \\
\text { yang muncul }\end{array}$ & 8 & $\begin{array}{l}\text { Masih ada sisa material } \\
\text { produksi yang mengeras } \\
\text { tertinggal }\end{array}$ & 6 & $\begin{array}{l}\text { Membersihkan dan } \\
\text { mengeluarkan sisa-sisa } \\
\text { material yang tertinggal }\end{array}$ & 8 & 384 & 3 \\
\hline \multirow[t]{2}{*}{ Buram } & $\begin{array}{l}\text { Silicone } \\
\text { menempel pada } \\
\text { permukaan part } \\
\text { bening }\end{array}$ & 3 & $\begin{array}{l}\text { Penyemprotan silicone } \\
\text { yang berlebihan }\end{array}$ & 3 & $\begin{array}{l}\text { Memberi arahan pada } \\
\text { operator }\end{array}$ & 1 & 9 & 11 \\
\hline & $\begin{array}{l}\text { Adanya debu } \\
\text { sisa crusher } \\
\text { (ampas) }\end{array}$ & 3 & $\begin{array}{l}\text { Penggunaan material } \\
\text { recycle }\end{array}$ & 6 & $\begin{array}{l}\text { Meganyak material } \\
\text { recycle }\end{array}$ & 3 & 54 & 9 \\
\hline Bercak & $\begin{array}{l}\text { Air chiller } \\
\text { tertinggal pada } \\
\text { permukaan mold }\end{array}$ & 6 & $\begin{array}{l}\text { Saluran pendinginan } \\
\text { molding bocor }\end{array}$ & 4 & $\begin{array}{l}\text { Menghubungi bagian } \\
\text { maintanance }\end{array}$ & 3 & 72 & 8 \\
\hline Kempot & $\begin{array}{l}\text { Injeksi kurang } \\
\text { padat }\end{array}$ & 2 & $\begin{array}{l}\text { Settingan injeksi mesin } \\
\text { kurang }\end{array}$ & 3 & $\begin{array}{l}\text { Menambah setingan } \\
\text { injeksi }\end{array}$ & 3 & 12 & 10 \\
\hline \multirow{2}{*}{ Short } & $\begin{array}{l}\text { Aliran material } \\
\text { tersumbat }\end{array}$ & 10 & $\begin{array}{l}\text { Adanya kotoran pada } \\
\text { nozzle }\end{array}$ & 3 & Membersihkan nozzle & 8 & 240 & 5 \\
\hline & $\begin{array}{l}\text { Pendinginan } \\
\text { terlalu cepat }\end{array}$ & 10 & Kecepatan injeksi kurang & 6 & $\begin{array}{l}\text { Menambah kecepatan } \\
\text { injeksi }\end{array}$ & 4 & 240 & 6 \\
\hline
\end{tabular}

part bening. Tabel 8 dan 9 adalah total reject setelah dilakukan berbagai langkah perbaikan yaitu dengan:

1. Material dipanaskan/dikeringkan terlebih dahulu sebelum dilanjutkan ke proses injeksi dengan cara menggunakan oven cadangan selama 4 jam dengan temperatur optimal untuk pengeringan bahan material yang akan digunakan yaitu $80-85^{\circ} \mathrm{C}$.

2. Pada komposisi material yang digunakan menurunkan banyaknya material recycle yang digunakan. Komposisi material recycle dari 50\% menjadi 35\%.

3. Pada produksi part Big Container 211PLY penyebab terjadinya retak dikarenakan pemberian pelumas yang kurang dengan itu melakukan pemberian pelumas setiap 2 kali mesin berproduksi untuk meminimalkan terjadinya cacat retak .

4. Melakukan pengecekan berkala apakah agar tidak ada operator yang lalai dalam mengoperasikan proses produksi.
Tabel 8. Hasil Implementasi Big Container

\begin{tabular}{|c|c|c|c|}
\hline Produksi & Cacat & $\begin{array}{l}\text { Banyak } \\
\text { Produksi }\end{array}$ & $\begin{array}{l}\text { Reject } \\
(\%)\end{array}$ \\
\hline Produksi 1 & 28 & 2.392 & 1,17 \\
\hline Produksi 2 & 35 & 1.783 & 1,96 \\
\hline Produksi 3 & 45 & 2.538 & 1,77 \\
\hline Produksi 4 & 49 & 2.283 & 2,15 \\
\hline Produksi 5 & 46 & 3.578 & 1,29 \\
\hline Produksi 6 & 44 & 2.566 & 1,71 \\
\hline Produksi 7 & 29 & 2.313 & 1,25 \\
\hline Produksi 8 & 31 & 1.578 & 1,96 \\
\hline Total & 307 & 19.031 & 1,61 \\
\hline
\end{tabular}

Tabel 9. Hasil Implementasi Big Container $1 \mathrm{~L} \mathrm{AS}$

\begin{tabular}{lrrr}
\hline Produksi & Cacat & $\begin{array}{c}\text { Banyak } \\
\text { Produksi }\end{array}$ & $\begin{array}{c}\text { Reject } \\
(\%)\end{array}$ \\
\hline Produksi 1 & 174 & 15.662 & 1,11 \\
Produksi 2 & 107 & 9.856 & 1,09 \\
Produksi 3 & 88 & 7.892 & 1,12 \\
Produksi 4 & 199 & 15.874 & 1,25 \\
Produksi 5 & 86 & 9.326 & 0,92 \\
Produksi 6 & 185 & 17.330 & 1,07 \\
Produksi 7 & 89 & 8.896 & 1,00 \\
Produksi 8 & 86 & 7.895 & 1,09 \\
\hline Total & 1.014 & 92.731 & 1,09 \\
\hline
\end{tabular}




\section{E. Control}

Berdasarkan hasil implementasi di atas maka, dilakukan kembali perhitungan DPMO dan peta kendali $\mathrm{P}$ untuk membuktikan apakah terjadi penurunan waste dan peningkatan nilai sigma.

Tabel 10. Hasil DPMO Implementasi Big Container 211 PLY

\begin{tabular}{ll}
\hline Keterangan & \\
\hline Unit & 19.031 \\
Oportunities & 6 \\
Defect & 307 \\
Defect per unit & 0,016131575 \\
Total Opportunities & 114.186 \\
Defect Per opportunities & 0,002688596 \\
DPMO & $2.688,5958$ \\
Tingkat Sigma & 4,283523807 \\
\hline
\end{tabular}

Dapat dilihat pada Tabel 10 dan 11, dapat disimpulkan bahwa terjadi penurunan \% reject menjadi $1,61 \%$ dan 1,09\%, sedangkan peningkatan sigma menjadi level 4,28 dan 4,40 pada part bening Big Container 211 PLY dan Big Container 1L AS. Peta kendali P untuk hasil implementasi dapat dilihat pada Gambar 8 dan 9.
Tabel 11. Hasil DPMO Implementasi Big Container 1L AS

\begin{tabular}{ll}
\hline Keterangan & \\
\hline Unit & 92.731 \\
Oportunities & 6 \\
Defect & 1.014 \\
Defect per unit & 0,010934855 \\
Total Opportunities & 556.386 \\
Defect Per opportunities & 0,001822476 \\
DPMO & $1.822,475763$ \\
Tingkat Sigma & 4,407358546 \\
\hline
\end{tabular}

\section{KESIMPULAN}

Berdasarkan analisis dan pengolahan data dapat disimpulkan bahwa: jenis cacat yang paling banyak terjadi pada kedua part Big Container 211 PLY dan 1L AS adalah jenis cacat silver dan retak. Sebelum dilakukan perbaikan nilai sigma untuk part Big Container 211 PLY dan 1L AS adalah 4,015 dan 4,199 dengan tingkat presentase reject 3,57\% dan 2,09\%. Sesudah implementasi nilai sigma untuk part Big Container 211 PLY dan 1L AS adalah 4,28 dan 4,40 dengan tingkat presentase reject $1,61 \%$ dan 1,09\%. Penyebab utama dari reject part bening ialah kurangnya pengeringan material dan banyaknya bahan material recycle.

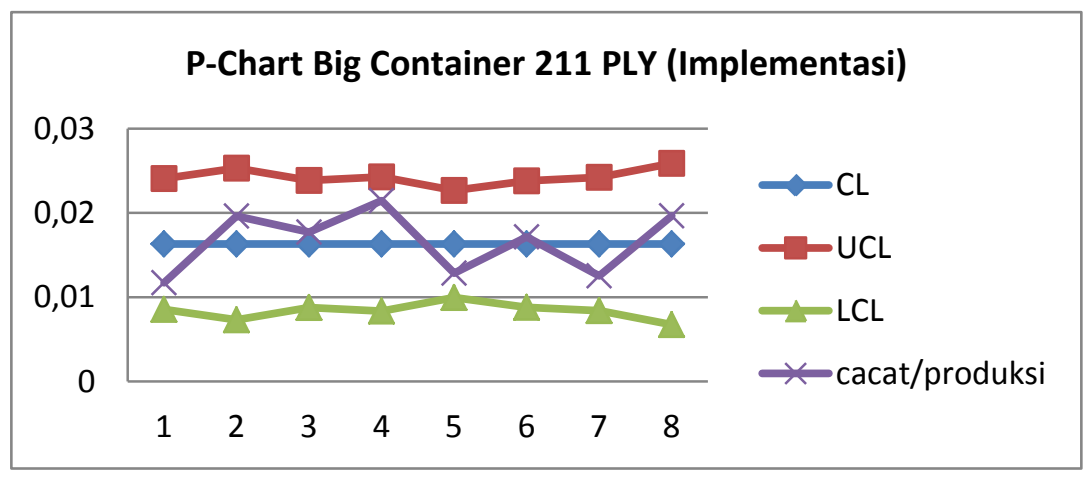

Gambar 8. Peta Kendali P Untuk Hasil Implementasi Big Container 211 PLY

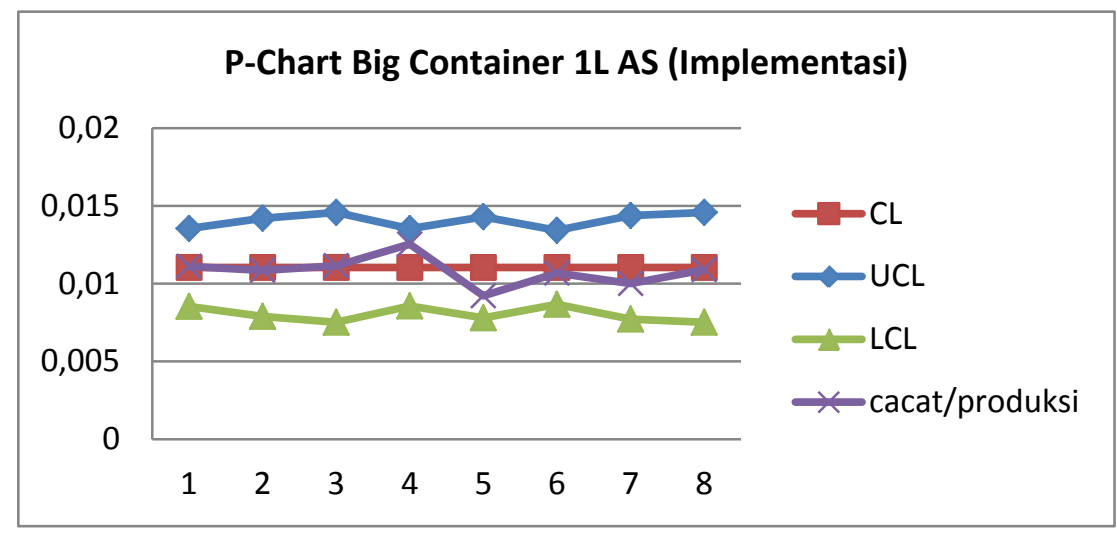

Gambar 9. Peta Kendali P Untuk Hasil Implementasi Big Container 1 L AS 
Terjadi perubahan yang mengarah kepada perbaikan kualitas setelah dilakukan implementasi pada proses injeksi part bening.

\section{DAFTAR PUSTAKA}

[1] Fitriati, Afia R., 2007, Pengantar Six Sigma. Salemba Empat, Jakarta.

[2] Gazperz, Vincent, 2007, Lean Six Sigmafor Manufacturing and Service Industries, Gramedia, Jakarta.
[3] Krishnamoorthi, K. S., 2006, A First Course in Quality Engineering, Pearson Prentice Hall, United State of America.

[4] Montgomery, Douglas C., 2004, Introduction to Statical Quality Control 4th Edition, John Wiley \& Sons (ASIA) Pte Ltd. Singapore. 